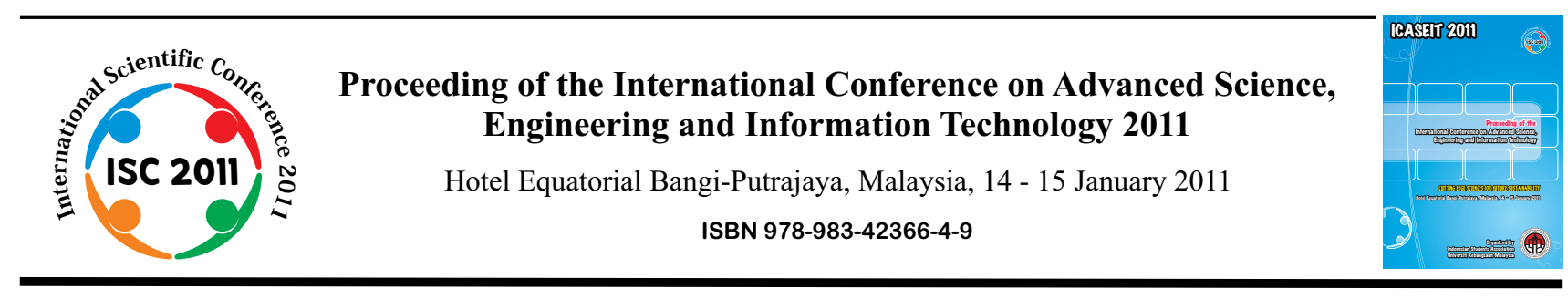

\title{
Minimalist Architecture; Discussion of Its Sustainability in Indonesia
}

\author{
Silfia Mona Aryani \\ Interior Design Department, Sebelas Maret University \\ Jl. Ir. Sutami 36 A Surakarta 57126 Indonesia \\ Tel.:+62-271-663367,E-mail: Mona aryani@uns.ac.id
}

\begin{abstract}
Architecture develops along with particular society changing. In the period of modern, some traditional architecture with their complex rules become considered old fashioned. It was not implemented in modern buildings. When functionality becomes priority, minimalist architecture, recognized as Neo-Modernism, spreads and offers reflection of modern lifestyle. However, every style is not always suitable for each circumstance. The unconditional application of style can create another problem instead of a solution. This essay will discuss the existence of minimalism in architecture; its historical relationship with modernism, the theoretical reviews which underpin the discussion and the appropriate adaptations need to be made to fit in tropical climate.
\end{abstract}

Keywords - Minimalist architecture, tropical climate, sustainability.

\section{INTRODUCTION}

Architecture develops al ong w ith par ticular soc iety changing especially in relation to their way of life, since it is a product of culture. Rudofsky (1981) introduces the term of "architecture witho ut architect" in cases of re cognizing the traditional architecture excellence that our ancestors did not follow scien tific me thods to cre ate their a rchitecture. They just found it ins tinctively by trial and er ror proc ess over a long period, so called evolution [1].

In the period of modernity, when eve rything had to be done in the name of fu nction, some traditional a rchitecture values wit $\mathrm{h}$ the ir com plex rules becom e c onsidered old fashioned and rare to be i mplemented in mode rn buildings. It $m$ ay be because most pe ople ma y n ot want to use it or could $\mathrm{n}$ ot build it [2]. Moreover w hen pe ople te nd to be "...dynamic, practical and active..." [3], they look for t ype of arc hitecture t hat re flects $t$ heir 1 ifestyle si nce " the architecture is the physical expr ession ... i t fol lows a particular life" [4]. Re cently, a new wave spr eads the concept of minimalism that seems to be a perfect answer of current society searching for the latest new thing.

However, eve ry style is $n$ ot alwa ys su itable for eac $h$ circumstance. In a ddition, the unconditional a pplication of style can create another problem instead of a solution. This essay will discuss the existence of $m$ inimalist a rchitecture; its historical relationship with modernism, the theoretical reviews which underpin the discussion and the a ppropriate adaptations need to be made to fit in tropical climate.

\section{BACKGROUND}

\section{A. Minimalist House Trend}

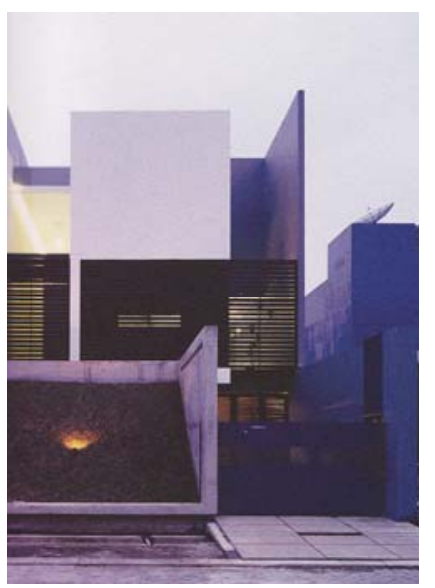

Fig. 1 A minimalist house; representing geometrical form

Minimalist houses have been popular since 2004s and are still likely to be a favourite choice besides Classic and Neoclassic styles in the next couple of y ears [5]. Reference [6] 
describes the minimalist architecture characteristics as “... geometrics in design, efficient concept, open plan and simple house".

Its pe rformance had already been represented by the Le Corbusier desi gn, V illa S avoye that $\mathrm{w}$ as built in 19 28: a modern arc hitecture p roduct. Its co ncept of efficiency and simplicity seems similar with the functionality of modernism based on " form follows functions" of Sullivan and "less is more" of Corbusier.

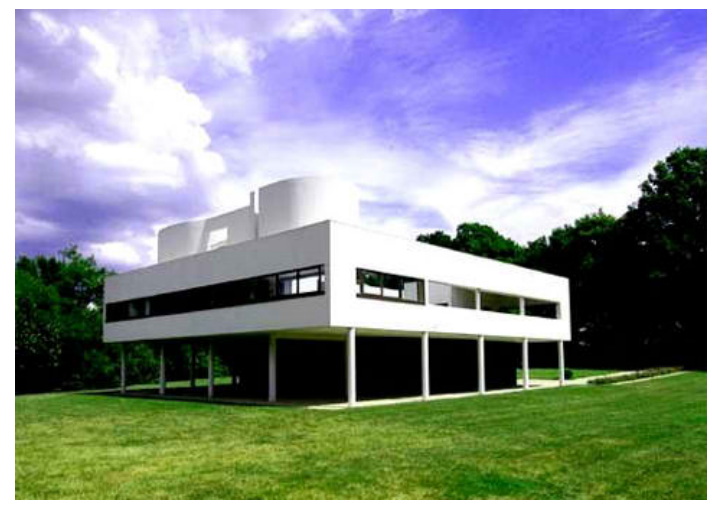

Fig. 2 Villa Savoye as an example of modern architecture

\section{B. Historical Reviews}

Some similarities abo ve le ad to an an xiety that the collapse of $m$ odernism in a rchitecture $m$ ay a lso ha ppen to minimalism, since it is called ne o-modernism. A s widely known fr om the pas $t$, at the e nd of m odern per iod, architecture gave a 1 ot o f p riority to f unctionality. Th is condition was su pported by the p racticality of using fabricated materials i $\mathrm{n}$ m odules tha $\mathrm{t}$ make it po ssible t o finish a project in shorter time than ever before. The "form follows fu nction" c oncept of S ullivan c hanged to $f$ orm follows fa brication $t$ hat 1 ater 1 eft o ut de sign proc ess considerations.

A most noticeable event of modern architectural history is Pruitt I goe ho using pr oject (1955) in S t. Lo uis, Miss ouri, USA, designed by Minoru Yamasaki [7].

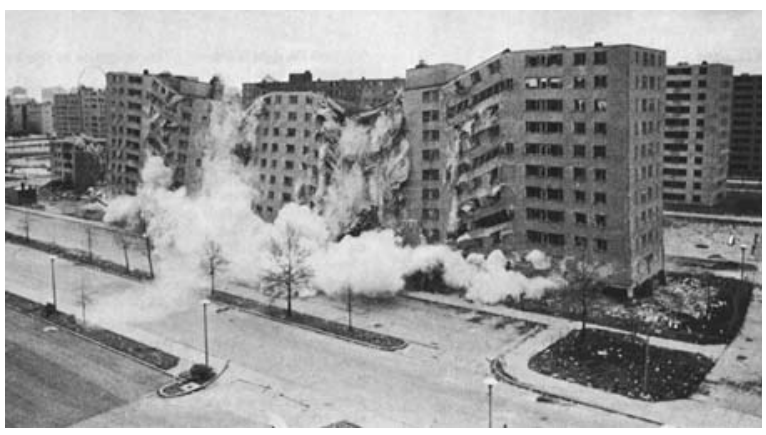

Fig. 3 The demolition of Pruitt-Igoe apartments

Originally it was built to settle the community in separate buildings but in the same area (Pruitt was for black residents and I goe $\mathrm{w}$ as for $\mathrm{w}$ hites) but it became inte grated a $\mathrm{i}$ ts opening. Ten yea rs after they ha $d$ bee $n$ occ upied, $t$ he management had to tear s ome buildings down to save the others. $\mathrm{H}$ aving fai led i n prob lem solv ing, the apa rtments created new problems in th e community such as v andalism and racism. This bad situation continued until 1972 when the Housing Authority decided on demolition of the apartments. This eve nt is thought to represent as the c ollapse of modernism in architecture. Re ference [8] argue s th at it fell because $t$ he architect did no $t$ consider the co ntextual requirement such as where the buil dings were going to be built, what kind of community will use the buildings and the importance of the how particular culture they belong to.

\section{Research Concern}

This scena rio cou ld happen in minimalist ar chitecture, since some designers $\mathrm{m}$ ight be $\mathrm{m}$ isunderstanding about the exact $\mathrm{c}$ haracteristics of it a nd ap ply the sa me desig ns to different context wi thout thinking of the specific condition, historically and culturally. That is why some design becomes uncomfortable, such as unpr actical because the bui ldings need a lot of regular tre atment a nd de pendent on art ificial equipment and is unsuitable for users' ways of life.

\section{LITERATURE REVIEWS.}

\section{A. Minimalist Architecture}

According to John Pawson, an architect who is known as one of the minimalism pioneers in architecture, minimalism is defined it as "... making the best possible contexts for the things which matter in life, on paring back the accretions of surface and behaviour to w hat essential...". It has goal to create ease fo $r$ physic al body [4]. O ther arc hitects fr om Bredemeyer Consulting, Malan and Bredemeyer [9] expl ain it as appr oach that "... sort out what y our hig hest p riority architectural requirements are, then do the least you possibly can do to achieve them!". Similarly Nurdiani [3] describes it as "... the way of thinking, a way of new approach in seeing design as re flection of ur ban s ociety tha $t$ is eff icient, practical, clear, transparent and enjoyment in limitation".

Reference [10] in his t heses see s Indonesia's minimalist architecture has developed in $\mathrm{t}$ wo tendencies. On the one hand, minimalist a rchitecture see $\mathrm{ms}$ to be experimentalism of architecture w hich is importa nt for deve lopment of architecture. On the other ha nd, $m$ inimalist has bee $n$ u sed only for labelling particular type of architectural presentation for marketing purposes.

\section{B. Traditional Architecture}

According to Miratab [11], vernacular architecture gives solution as a problem sol ving t hat environmentally, sustainable and socia lly f ulfilling. This $\mathrm{m}$ ay be cause th $\mathrm{e}$ architecture i ntegrates specific oc cupant ac tivities and provides supported con dition by ac commodating $\mathrm{w}$ hether ecological, c ultural, ec onomic, pol itical, spi ritual or soc ial. Moreover, $t$ raditional ar chitecture in Ind onesia has been researched in its development to adapt with tropical climate. The adaptations are proved suitable for tropical architectural requirement that $\mathrm{c}$ onsidering $\mathrm{c}$ limate influences in occupant's comfort. Reference [1] points out the purposes of the adaptations based on the characteristics of the roof with 
its ventilation, the $\mathrm{w}$ all as bre athing divider a nd the flo or with its brea thing material tha $t$ proved cre ated $t$ hermal comfort.

\section{Tropical Architecture}

Troppo architects, discussed by Philip Goad in reference [10] has em phasized the g ood princ iples of tropica 1 house design in their 'Punkahs and Pith Helmets'; a report of top end housing research on June 1982. They are

1. The promotion of cooling breezes

2. Ventilation by convection

3. Reducing radiation of heat

4. Sheltering of walls and openings

Those $\mathrm{p}$ rinciples ha $\mathrm{d}$ been app lied b y our ancestor for constructing tr aditional arc hitecture. They had c onsidered geographical prerequisite and anticipated the climate.

\section{TROPICAL MINIMALIST ARCHITECTURE}

There i s stron $g$ argum ent th at the qua lity of de sign is assessed by whether people feel comfort or not when using a building. It means that good a rchitecture re quires c reating comfort as well as including climate consideration. Similar with that statement, minimalist architecture actually has goal to create physical comfort. However it can be argued that the general cha racteristics of minimalist arc hitecture ca nnot be directly implemented into house design in Indonesia because they do not include some adjustments for specific conditions, climate for example.

Adapting every style of architecture including minimalist to be suitable for a tropical region can be done by modifying the $\mathrm{m}$ icroclimate, desi gning the bu ilding $\mathrm{w}$ ith a passive system approach and using additional equipment as the last alternative [12]. The solution that is closely rela ted to the style of a rchitecture i s the second on e: a $\mathrm{p}$ assive sy stem design a pproach that $\mathrm{m}$ akes poss ible for the building $\mathrm{t} o$ create its own comfort.

Traditional architecture in Indonesia might be recognised as a rchitecture of the $r$ oof. That sta tement is suppor ted by Samodra in research findings [13] that the most in fluential part of house to create thermal comfort is the roof. The roof must be a breath ing surfa ce such as roof tiles $n$ ot a to tal concrete roof bec ause it is pos sible for the fresh $w$ ind to blow in through the fissures between the tiles. This new air pushes and replaces the old that is already hot because of sun radiation. The roof also shall be $\mathrm{i} n$ two layer type for ensuring that the hot a ir be cause of $\mathrm{t}$ he sun ra diation is trapped in space betw een layers. Ther efore the $t$ rapped hot air $w$ ill no $t$ heat up the room and $t$ he occupants. Roo $f$ existence can be expanded as its sun shading function. For these reasons the passive approach of minimalist architecture might be more optimal in creating thermal comfort by using appropriate su $\mathrm{n}$ shading to protect the window from over sunlight that can heat the indoor thermal.
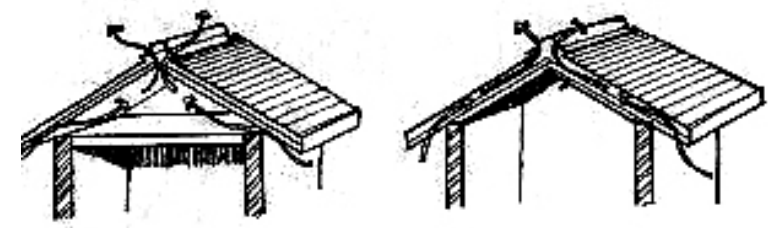

Fig. 4 Two layer roof system
Another solution is designing the wall as the second skin. Based on Hardiman's observation [1] the good wall must be formed $w$ ith breathing $m$ aterial so the ai $r$ ca $n$ continually change to make the indoor air kee $p$ healthy. The brea thing material does not have to be made from wood or bamboos just like $\mathrm{t}$ he $\mathrm{t}$ raditional $\mathrm{h}$ ouse often uses si nce it $\mathrm{m}$ ight become unpractical, but can be created with using windows that still allow wind to enter even when it is closed.

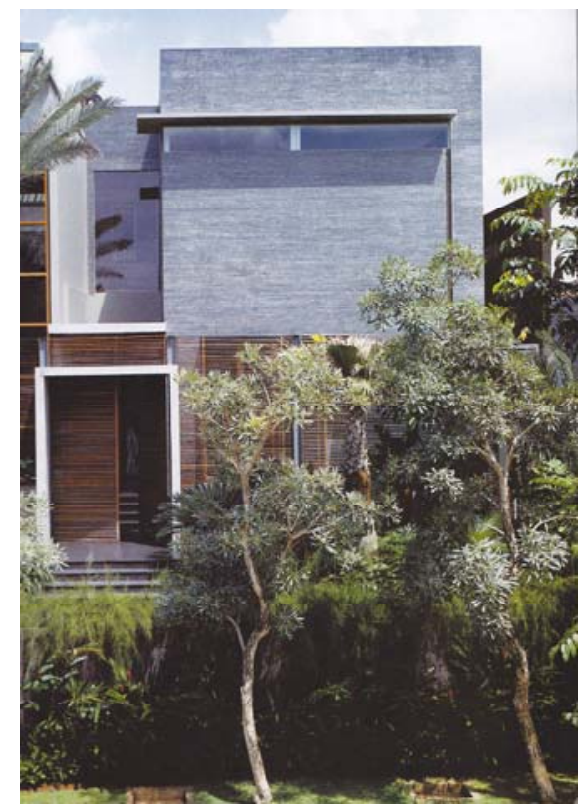

Fig. 5 Appropriate shading and breathing wall

The last solution is dea ling with the house orientation. It will be a benefit to have good orientation for example south, but it does not mean that we cannot do anything if the house has to face the most difficult direction. Using a barrier might be righ $t$ dec ision that cou ld be in form of vege tation or a massive wall. In some cases must be $\mathrm{c}$ onsidered if $\mathrm{t}$ he position of the bar rier is $t$ he on ly o pportunity to $\mathrm{p}$ ut a $\mathrm{n}$ opening such as windows and doors. Double facade can be implemented, just as $\mathrm{C}$ olonial a rchitecture $\mathrm{d}$ id f or its adaptation $\mathrm{t} o$ tropical c limate. On th $\mathrm{e}$ other ha nd, Suryabrata's idea [13] of u sing "saw-like" form could be an appropriate suggestion. That form is purp osed to c ope the unfortunate sunlight orientation, by opening arrangements to create $\mathrm{cr}$ oss ve ntilation, plac ing $\mathrm{w}$ indow to o ptimize $\mathrm{d}$ ay lighting and using higher temperature settings to reduce the demand of colder temperature.

\section{CONCLUSIONS}

Despite of its similarity with modernism, minimalist style in architecture actually can be suitable enough to be applied in a tropical climate like Indonesia as long as the design is made with climate consideration. This approach would make the building creates its own thermal comfort as an adaptation of conditional requirements. By bei ng less dependent from artificial support, the minimalist architecture could reach its main goa 1 in $\mathrm{c}$ reating ease for the phys ical b ody i $\mathrm{n}$ a sustainable way. 


\section{ACKNOWLEDGMENT}

I w ould thank to Carmel D arling, my proof reader and editor of this essay.

\section{REFERENCES}

[1] G. Ha rdiman, “ The wisdom of tr aditional architecture i n Indonesia to anticipate the problem of the thermal comfort inside the bu ilding", in The $6^{\text {th }}$ International Se minar on S ustainable Environment and Architecture, 2005.

[2] C. Mitcham, "Thinking re-vernacular building", Design Iss ues, 21, 1, pp. 32-40, 2005

[3] N. N urdiani, "The minimalist hous e d esign in Ja karta and its response to the tropical c limate", in The $6^{\text {th }}$ Internati onal Seminar of Sustainable E nvironment and A rchitecture, 2005, p.37

[4] J. Pa wson (200 4), Minimalism, [Online]. Ava ilable: http: //www.johnpawson.com/essays/minimalism

[5] Eryudhawan, Arsitektur Masa $K$ ini; $P$ olarisasi $K$ lasik dan Minimalis, se r. Ma jalah IDEA in T ren $2005 \mathrm{R}$ umah $\mathrm{T}$ inggal Masa Kini, , Jakarta, Indonesia: 2005

[6] R.S. Seta, et.al . Rumah tinggal 2005, ser. Majalah IDEA in Tren 2005 Rumah Tinggal Masa Kini, Jakarta, Indonesia: 2005
[7] R.O. Ke el. (2006) Pruitt-Igoe and the E nd of M odernity, University of Missour i, S t. Louis, [Online]. Ava ilable: http://www.umsl.edu/ rkeel/pruitt-igoe.html

[8] Ikhwanuddin, Menggali Pe mikiran Pos tmodernisme dalam Arsitektur, Y ogyakarta, Indonesia: Ga djah Mada University Press, 2005

[9] R. Malan and D. Br edemeyer. (2002) 'Minimalist architecture', IT P ro, [Onl ine ]. Av ailable: http://www.bredemeyer.com/pdf files/ MinimalistArchitecture.PDF $>$.

[10] H. Kurnia wan, “ Arsitektur M inimalist; Konsep, $\mathrm{P}$ rinsip da $\mathrm{n}$ Metoda", M.T. thesis S2, Gadjah Mada University, Yogyakarta, Indonesia, 2009,p.270

[11] F. Miratab, "Sustainability in environmental design: case studies from the vernacular tradition in Iran", Australian Planner, vol 36, 4 pp. $210-215,1999$

[12] J.A. Su ryabrata, " Passive an d low energy ar chitecture; an alternative design approach for sustainable development", in The $6^{\text {th }} I$ nternational $S$ eminar o f Sustainable Environment and Architecture, 2005

[13] F.X.T. Sam odra, "Thermal p erformance opt imization for Javanese vill age Houses", in The $6^{\text {th }}$ International Se minar of Sustainable Environment and Architecture, 2005 